\title{
Financial Distress Prediction: Case Study Plantation Companies Listed on Indonesia Stock Exchange
}

\author{
Uki Rivendra $^{1}$, Sudjono ${ }^{2}$, Ahmad Badawi Saluy ${ }^{3}$ \\ \{uki.rivendra@gmail.com¹, sudjono@mercubuana.ac.id ${ }^{2}$, ahmad.badawi@mercubuana.ac.id ${ }^{3}$ \} \\ Mercu Buana University, Jakarta, Indonesia ${ }^{123}$
}

\begin{abstract}
The decline in the level of export, the decline in the price of crude palm oil and the decline in the Indonesian economy are predicted to cause financial distress in the plantation sub-sector companies in Indonesia. This study aims to test empirically the financial distress condition of oil palm sub-sector companies using the Altman Modification and Zavgren prediction models. The Companies that become population in this study were Plantation sub-sector Companies listed on Indonesia Stock Exchange in the period 2013-2017. Research result shows that Modified Altman and Zavgren Model can be used to predict the Financial Distress of Plantation sub-sector Companies in the 2013-2017 period, and there are differences between two prediction models, where Modified Altman are more accurate than Zavgren model.
\end{abstract}

Keywords: Financial Distress, Plantation Companies, Modified Altman, Zavgren

\section{Introduction}

The palm oil industry as one of Indonesia's national strategic industries that play a role in generating foreign exchange has become one of the biggest contributors to gross domestic product and absorbs national employment. Behind the grandeur of the achievements of the palm oil industry, many pressures faced by the palm oil industry, weakening global market demand led to a decline in the level of palm oil exports that is not comparable with the level of production that continues to increase, the price of palm oil commodities that experienced a good downward trend caused by an economic crisis in the European Union as well as the negative sentiments blown by the European Union towards the palm oil industry. From picture 1 above illustrates the declining trend of CPO prices which in 2010 was at 1,200 USD / MT, decreased until 2018 to the point of 600 USD / MT, wherein ten years it can be said that CPO prices have decreased by $50 \%$. These pressures can cause financial hardship conditions for oil palm plantation companies and can also cause bankruptcy, but in reality, there were no oil palm plantation companies that were delisted from IDX during the 20132017 period, so these conditions are interesting to study.

Financial Distress Prediction is an interesting thing to be used as a research, many studies on Financial Distress predictions have been produced because the Financial Distress prediction can be used by company management to measure the level of the company's financial condition. This study aims to predict the financial difficulties of the plantation subsector companies listed on the Indonesia Stock Exchange in the 2013-2017 period using the Altman Modification model and the Zavgren model. Financial Distress is a phenomenon that indicates a decline in the financial performance of a company. Bankruptcy will occur if there 
is an omission of a decline in financial performance. The history of financial crises shows that financial difficulties are phenomena with repetitive cycles and have clear and almost unchanging characteristics [7]. According to Brealey [3], High debt ratios mean that more companies are likely to fall into financial distress when a serious recession hits the economy.

According to M. Salim [9], "analysis of financial difficulties or bankruptcy of the company is very important for various parties". Financial bankruptcy prediction analysis is conducted to obtain an early warning of company bankruptcy, so that company management can immediately take preventative measures. According to Badawi [2], "Company Management must be able to provide information to related parties regarding the achievement of the success of operational policies", which means that the Company's Management must have a tool to measure the level of corporate health that can be accounted for.

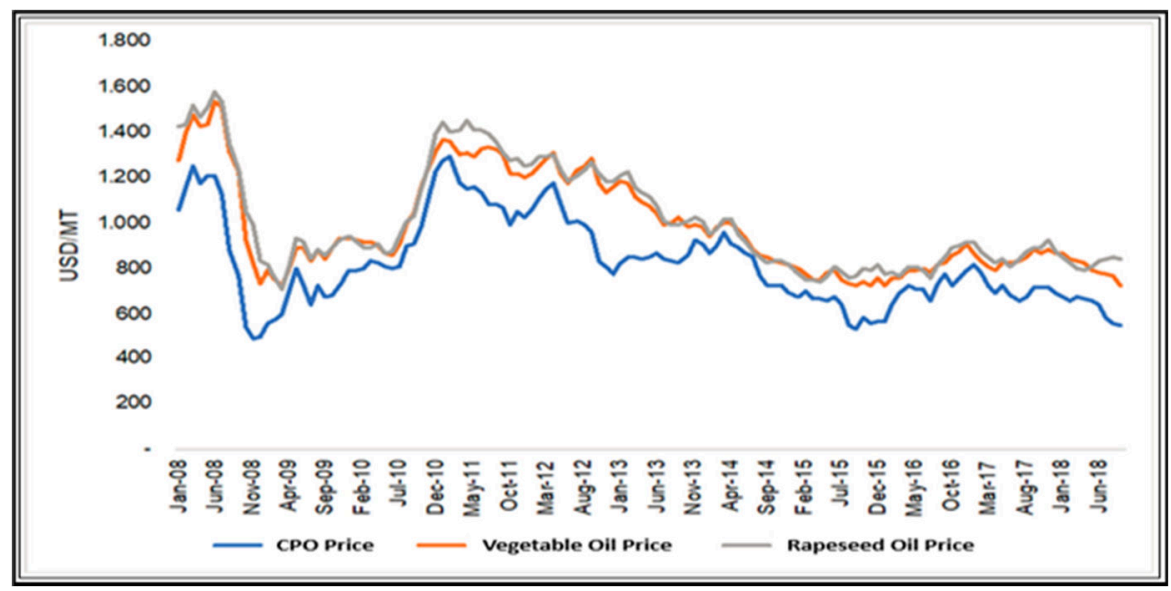

Fig 1. CPO Price Declining

\section{Research Method}

This research is descriptive quantitative research, descriptive quantitative research according to Khotari [5], is a research-based on measuring quantity or amount and researchers have no control over variables, researchers can only inform what is happening or what is happening. This research step is to collect, classify, analyze, and interpret data on the financial statements of oil palm plantation companies listed on the Indonesia Stock Exchange for the period 2013-2017.

\subsection{Modified Altman model}

Altman [1], analyzed 66 samples of companies that were processed using a bankruptcy risk prediction model, of the 66 samples consisting of two groups, 33 bankrupt and 33 not bankrupt. Altman uses five financial ratios that are mixed into a prediction model for the Company's bankruptcy. Then in 1995, Altman modified the formula released from 1968, so that the formula became flexible and could be used in all conditions of manufacturing and non-manufacturing companies, public or non-public, by eliminating the X5 variable. Modified Altman formula 1995 as follows [4]: 


$$
Z=6.56 X 1+3.26 X 2+6.72 X 3+1.05 X 4
$$

Information:

X1: Working Capital / Total Assets, X2: Retained Earnings / Total Assets, X3: Earnings before Interest and Tax / Total Assets, X4: Market Capitalization / Book Value of Debt

The modified Altman model uses the cut-off point as follows: If the $\mathrm{Z}$ value is above 2.60 , it will be classified as a healthy company, If the $Z$ value is between 1.10 to 2.60 , it will be classified as a company in the grey area and If the $\mathrm{Z}$ value is below 1.10 , it will be classified as a distressed company

\subsection{Zavgren logit model}

In 1985 Zavgren [10], proposed a model that could predict bankruptcy. This model classifies variable data into two groups of bankrupt and non-bankrupt, Zavgren's model analysis presents the probability of bankruptcy in assessing the level of management effectiveness. 45 samples of companies used by Zavgren in this model, some companies are bankrupt and not bankrupt with a scale of $50 \%$ probability, Zavgren states that this model has an accuracy rate of $82 \%$. To use the Zavgren model, it must go through four stages. According to Rahmawati [8], the first stage is to arrange seven financial ratios, the second for the value of the ratio is multiplied by the value of a special constant, the three multiplication values will be added together to get the value (y). Then the results of the (y) value will be assessed by the bankruptcy group as follows:

1

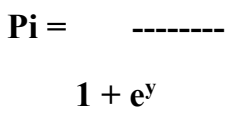

Where the rank value of $y$ is multivariable consisting of constants and coefficients of variables (financial ratios). For the value of (e) is a natural number which has a value of 2.1828. The Zavgren model uses logit to classify bankrupt and non-bankrupt companies, the model is as follows:

$$
\begin{gathered}
Y=0.23883-0.108(I N V)-1.583(\text { REC })-10.78(C A S H)+3.074(\text { QUICK })+0.486(\text { ROI })- \\
4.35(D E B T)+0.11(T U R N)
\end{gathered}
$$

Information:

$\mathrm{Y}=$ Coefficient value, $\mathrm{INV}=$ Inventory $/$ Sales, $\mathrm{REC}=$ Receivables $/$ Inventory, $\mathrm{CASH}=$ Cash / total assets, QUICK $=$ Current Assets / Current Debt, ROI = Net Operating Profit / (Total Assets - Current Debt), DEBT = Long-term Debt / (Total Assets - Current Debt), TURN $=$ Sales / (Working Capital + Fixed Assets)

\subsection{Sampling}

The method used in taking research samples is purposive sampling. According to Priyono [6], "purposive sampling or judgmental sampling is a sampling technique by determining certain criteria to be selected as sample members". The sample of selected plantation subsector companies has the following criteria:

a. Palm oil sub-sector companies listed on the Stock Exchange starting in early 2013-2017.

b. The plantation sub-sector company published a complete audited financial report. 
In the period 2013-2017, there were 18 plantation sub-sector companies listed on the IDX, wherein this study sampling will be conducted by following the above criteria so that 11 selected sample companies are obtained.

Table 1. Sample Companies

\begin{tabular}{ccl}
\hline No & Code & \multicolumn{1}{c}{ Companies } \\
\hline 1 & AALI & PT. Astra Agro Lestari TBK \\
2 & BWPT & PT. Eagle High Plantation TBK \\
3 & GZCO & PT. Gozco Plantation TBK \\
4 & JAWA & PT. Jaya Agra Wattie TBK \\
5 & LSIP & PT. London Sumatra Indonesia TBK \\
6 & PALM & PT. Provident Agro TBK \\
7 & SGRO & PT. Sampoerna Agro TBK \\
8 & SIMP & PT. Salim Invomas Pratama TBK \\
9 & SMAR & PT. Smart TBK \\
10 & TBLA & PT. Tunas Baru Lampung TBK \\
11 & UNSP & PT. Bakrie Sumatra Plantations TBK \\
\hline
\end{tabular}

Source: Data processed by researchers

\section{Results and Discussion}

\subsection{Descriptive statistics}

3.1.1 Altman Descriptive Statistics

Data variable that used in the Altman model can be described as below:

Table 2. Altman Descriptive Statistics

\begin{tabular}{lcccc}
\hline & $\mathrm{X} 1$ & $\mathrm{X} 2$ & $\mathrm{X} 3$ & $\mathrm{X} 4$ \\
\hline Max & 0.189 & 0.656 & 0.228 & 9.676 \\
Min & -0.746 & -0.525 & -0.063 & 0.015 \\
Mean & -0.042 & 0.198 & 0.064 & 1.766 \\
Std. Dev. & 0.167 & 0.255 & 0.056 & 2.381 \\
\hline $\mathrm{N}$ & & & 55 &
\end{tabular}

Source: Data processed by researchers

\subsubsection{Altman Descriptive Statistics}

Data variable that used in the Altman model can be described as below:

Table 3. Zavgren Descriptive Statistics

\begin{tabular}{lllccccc}
\hline & INV & REC & CASH & QUICK & ROI & DEBT & TURN \\
\hline Max & 0.396 & 1.224 & 0.175 & 5.209 & 0.268 & 1.228 & 4.341 \\
Min & 0.025 & 0.004 & 0.001 & 0.098 & -0.068 & 0.077 & -12.424 \\
Mean & 0.111 & 0.369 & 0.045 & 1.047 & 0.083 & 0.433 & 1.102 \\
Std. & & & & & & & \\
Dev. & 0.061 & 0.292 & 0.044 & 0.855 & 0.069 & 0.197 & 2.067 \\
\hline $\mathrm{N}$ & & & \multicolumn{7}{c}{55} & & \\
\hline
\end{tabular}

Source: Data processed by researchers 


\subsection{Analysis of the Financial Distress Prediction Model \\ 3.2.1. Model Formulation}

From the Altman model formula and the Zavgren model formula, the following predictions are generated.

Table 4. Altman and Zavgren Financial Distress Predictions

\begin{tabular}{|c|c|c|c|c|c|c|}
\hline Kode & Model & 2013 & 2014 & 2015 & 2016 & 2017 \\
\hline \multirow{2}{*}{ AALI } & Altman & Healthy & Healthy & Healthy & Healthy & Healthy \\
\hline & Zavgren & Healthy & Healthy & Healthy & Healthy & Healthy \\
\hline \multirow{2}{*}{ BWPT } & Altman & Grey Area & Distress & Distress & Distress & Distress \\
\hline & Zavgren & Distress & Grey Area & Grey Area & Grey Area & Grey Area \\
\hline \multirow{2}{*}{ GZCO } & Altman & Distress & Grey Area & Distress & Distress & Grey Area \\
\hline & Zavgren & Grey Area & Healthy & Healthy & Distress & Grey Area \\
\hline \multirow{2}{*}{ JAWA } & Altman & Grey Area & Grey Area & Distress & Distress & Distress \\
\hline & Zavgren & Grey Area & Grey Area & Distress & Distress & Distress \\
\hline \multirow{2}{*}{ LSIP } & Altman & Healthy & Healthy & Healthy & Healthy & Healthy \\
\hline & Zavgren & Healthy & Healthy & Healthy & Healthy & Healthy \\
\hline \multirow{2}{*}{ PALM } & Altman & Distress & Grey Area & Distress & Healthy & Healthy \\
\hline & Zavgren & Grey Area & Grey Area & Distress & Healthy & Grey Area \\
\hline \multirow{2}{*}{ SGRO } & Altman & Healthy & Healthy & Grey Area & Grey Area & Healthy \\
\hline & Zavgren & Healthy & Healthy & Healthy & Healthy & Grey Area \\
\hline \multirow{2}{*}{ SIMP } & Altman & Grey Area & Grey Area & Grey Area & Grey Area & Grey Area \\
\hline & Zavgren & Grey Area & Healthy & Healthy & Healthy & Grey Area \\
\hline \multirow{2}{*}{ SMAR } & Altman & Healthy & Healthy & Grey Area & Healthy & Healthy \\
\hline & Zavgren & Healthy & Healthy & Grey Area & Healthy & Healthy \\
\hline \multirow{2}{*}{ TBLA } & Altman & Grey Area & Grey Area & Grey Area & Grey Area & Grey Area \\
\hline & Zavgren & Grey Area & Grey Area & Grey Area & Grey Area & Grey Area \\
\hline \multirow{2}{*}{ UNSP } & Altman & Distress & Distress & Distress & Distress & Distress \\
\hline & Zavgren & Distress & Distress & Distress & Distress & Distress \\
\hline
\end{tabular}

From the table above, for the 2013-2017 period, the Altman model predicts 18 points of a distressed company, 18 points of a company in the grey area, and 19 points of a healthy company. For the 2013-2017 period, the Zavgren model predicts 11 points of distress for the Company, 20 points for the Company in the grey area, and 24 points for the healthy Company.

\subsubsection{Accuracy of the Financial Distress Prediction Model}

Researchers conducted a comparison test of the prediction results of the Altman and Zavgren distress model with the company's ROA conditions based on its financial statement 
data. Through this test, the researcher wants to know which prediction models have better accuracy. The comparison test results are as follows:

Table 5. Accuracy of Predictions

\begin{tabular}{|c|c|c|c|c|c|c|c|}
\hline No & & odel & 2013 & 2014 & 2015 & 2016 & 2017 \\
\hline 1 & AALI & $\begin{array}{l}\text { ROA } \\
\text { Altman } \\
\text { Zavgren } \\
\end{array}$ & $\begin{array}{c}12.72 \\
\text { Healthy } \\
\text { Healthy }\end{array}$ & $\begin{array}{c}14.12 \\
\text { Healthy } \\
\text { Healthy }\end{array}$ & $\begin{array}{c}3.23 \\
\text { Healthy } \\
\text { Healthy }\end{array}$ & $\begin{array}{c}8.73 \\
\text { Healthy } \\
\text { Healthy }\end{array}$ & $\begin{array}{c}8.48 \\
\text { Healthy } \\
\text { Healthy } \\
\end{array}$ \\
\hline 2 & BWPT & $\begin{array}{l}\text { ROA } \\
\text { Altman } \\
\text { Zavgren }\end{array}$ & $\begin{array}{c}2.93 \\
\text { Grey Area } \\
\text { Distress }\end{array}$ & $\begin{array}{c}1.19 \\
\text { Distress } \\
\text { Grey Area }\end{array}$ & $\begin{array}{c}-1.03 \\
\text { Distress } \\
\text { Grey Area }\end{array}$ & $\begin{array}{c}-2.41 \\
\text { Distress } \\
\text { Grey Area }\end{array}$ & $\begin{array}{c}-1.17 \\
\text { Distress } \\
\text { Grey Area }\end{array}$ \\
\hline 3 & GZCO & $\begin{array}{l}\text { ROA } \\
\text { Altman } \\
\text { Zavgren } \\
\end{array}$ & $\begin{array}{c}-2.99 \\
\text { Distress } \\
\text { Grey Area }\end{array}$ & $\begin{array}{c}1.58 \\
\text { Grey Area } \\
\text { Healthy }\end{array}$ & $\begin{array}{c}-0.64 \\
\text { Distress } \\
\text { Healthy } \\
\end{array}$ & $\begin{array}{c}-43.63 \\
\text { Distress } \\
\text { Distress } \\
\end{array}$ & $\begin{array}{c}-4.79 \\
\text { Distress } \\
\text { Grey Area }\end{array}$ \\
\hline 4 & JAWA & $\begin{array}{l}\text { ROA } \\
\text { Altman } \\
\text { Zavgren } \\
\end{array}$ & $\begin{array}{c}2.63 \\
\text { Grey Area } \\
\text { Grey Area }\end{array}$ & $\begin{array}{c}1.69 \\
\text { Grey Area } \\
\text { Grey Area }\end{array}$ & $\begin{array}{c}-0.35 \\
\text { Distress } \\
\text { Distress } \\
\end{array}$ & $\begin{array}{c}-6.84 \\
\text { Distress } \\
\text { Distress } \\
\end{array}$ & $\begin{array}{c}-6.04 \\
\text { Distress } \\
\text { Distress } \\
\end{array}$ \\
\hline 5 & LSIP & $\begin{array}{l}\text { ROA } \\
\text { Altman } \\
\text { Zavgren } \\
\end{array}$ & $\begin{array}{c}9.88 \\
\text { Healthy } \\
\text { Healthy }\end{array}$ & $\begin{array}{c}10.59 \\
\text { Healthy } \\
\text { Healthy } \\
\end{array}$ & $\begin{array}{c}7.04 \\
\text { Healthy } \\
\text { Healthy }\end{array}$ & $\begin{array}{c}6.27 \\
\text { Healthy } \\
\text { Healthy } \\
\end{array}$ & $\begin{array}{c}7.83 \\
\text { Healthy } \\
\text { Healthy } \\
\end{array}$ \\
\hline 6 & PALM & $\begin{array}{l}\text { ROA } \\
\text { Altman } \\
\text { Zavgren }\end{array}$ & $\begin{array}{c}-5.7 \\
\text { Distress } \\
\text { Grey Area }\end{array}$ & $\begin{array}{c}3.98 \\
\text { Grey Area } \\
\text { Grey Area }\end{array}$ & $\begin{array}{c}-1.18 \\
\text { Distress } \\
\text { Distress } \\
\end{array}$ & $\begin{array}{c}5.68 \\
\text { Healthy } \\
\text { Healthy }\end{array}$ & $\begin{array}{c}2.39 \\
\text { Healthy } \\
\text { Grey Area }\end{array}$ \\
\hline 7 & SGRO & $\begin{array}{l}\text { ROA } \\
\text { Altman } \\
\text { Zavgren }\end{array}$ & $\begin{array}{c}2.67 \\
\text { Healthy } \\
\text { Healthy }\end{array}$ & $\begin{array}{c}\quad 6.4 \\
\text { Healthy } \\
\text { Healthy }\end{array}$ & $\begin{array}{c}3.51 \\
\text { Grey Area } \\
\text { Healthy }\end{array}$ & $\begin{array}{c}5.52 \\
\text { Grey Area } \\
\text { Healthy }\end{array}$ & $\begin{array}{c}3.66 \\
\text { Healthy } \\
\text { Grey Area }\end{array}$ \\
\hline 8 & SIMP & $\begin{array}{l}\text { ROA } \\
\text { Altman } \\
\text { Zavgren }\end{array}$ & $\begin{array}{c}2.33 \\
\text { Grey Area } \\
\text { Grey Area }\end{array}$ & $\begin{array}{c}3.58 \\
\text { Grey Area } \\
\text { Healthy }\end{array}$ & $\begin{array}{c}1.15 \\
\text { Grey Area } \\
\text { Healthy }\end{array}$ & $\begin{array}{c}1.86 \\
\text { Grey Area } \\
\text { Healthy }\end{array}$ & $\begin{array}{c}2.08 \\
\text { Grey Area } \\
\text { Grey Area }\end{array}$ \\
\hline 9 & SMAR & $\begin{array}{l}\text { ROA } \\
\text { Altman } \\
\text { Zavgren } \\
\end{array}$ & $\begin{array}{c}.86 \\
\text { Healthy } \\
\text { Healthy }\end{array}$ & $\begin{array}{c}6.93 \\
\text { Healthy } \\
\text { Healthy } \\
\end{array}$ & $\begin{array}{c}\text {-1.61 } \\
\text { Grey Area } \\
\text { Grey Area }\end{array}$ & $\begin{array}{c}9.94 \\
\text { Healthy } \\
\text { Healthy }\end{array}$ & $\begin{array}{c}4.34 \\
\text { Healthy } \\
\text { Healthy } \\
\end{array}$ \\
\hline 10 & TBLA & $\begin{array}{l}\text { ROA } \\
\text { Altman } \\
\text { Zavgren } \\
\end{array}$ & $\begin{array}{c}1.39 \\
\text { Grey Area } \\
\text { Grey Area }\end{array}$ & $\begin{array}{c}5.96 \\
\text { Grey Area } \\
\text { Grey Area }\end{array}$ & $\begin{array}{c}2.16 \\
\text { Grey Area } \\
\text { Grey Area }\end{array}$ & $\begin{array}{c}4.93 \\
\text { Grey Area } \\
\text { Grey Area }\end{array}$ & $\begin{array}{c}6.8 \\
\text { Grey Area } \\
\text { Grey Area }\end{array}$ \\
\hline 11 & UNSP & $\begin{array}{l}\text { ROA } \\
\text { Altman } \\
\text { Zavgren }\end{array}$ & $\begin{array}{c}-15.36 \\
\text { Distress } \\
\text { Distress }\end{array}$ & $\begin{array}{c}-2.92 \\
\text { Distress } \\
\text { Distress }\end{array}$ & $\begin{array}{c}-3.06 \\
\text { Distress } \\
\text { Distress }\end{array}$ & $\begin{array}{c}-3.3 \\
\text { Distress } \\
\text { Distress }\end{array}$ & $\begin{array}{c}-11.82 \\
\text { Distress } \\
\text { Distress }\end{array}$ \\
\hline
\end{tabular}


Source: Data processed by researchers.

From the research results by comparing the Company's ROA with the predicted Financial Distress results, the accuracy for each model are as follows:

Table 6. Model Accuracy Level

\begin{tabular}{lccccc}
\hline \multirow{2}{*}{ Assessment } & \multicolumn{2}{c}{ Altman } & \multicolumn{2}{c}{ Zavgren } \\
\cline { 2 - 5 } & Appropriate & Unappropriated & Appropriate & Unappropriated \\
\hline Prediction & 53 & 2 & 46 & 9 \\
Accuracy \% & & 96.36 & & 83.64 \\
Error \% & & 3.64 & & 16.36 \\
\hline \multicolumn{1}{c}{$\mathrm{N}$} & & & \multicolumn{2}{c}{55} \\
\hline
\end{tabular}

Source: Data processed by researchers.

From the table above we get the result of the Altman model's prediction accuracy of $96.36 \%$ with an error rate of $3.64 \%$, for the prediction accuracy of the Zavgren model of $83.64 \%$ with an error rate of $16.36 \%$.

\section{Conclusion}

There is potential for bankruptcy from the predicted results of the Financial Distress model for plantation companies listed on the Indonesian Stock Exchange in the 2013-2017 period. In the 2013-2017 period, the results of the Altman model predictions obtained 18 distribution points for the distressed category, 18 distribution points for the grey area category, and 19 distribution points for the healthy category company. For the prediction results of the Zavgren model, there are 11 distribution points for the distressed category, 20 distribution points for the grey area category, and 24 points for the distribution category for the healthy category. Of the two Financial Distress prediction analysis models, the modified Altman model is the most accurate model predicting the distressed category for plantation subsector companies listed on the Indonesia Stock Exchange in the 2013-2017 period with a drain rate of $96.36 \%$ and an error rate of $3.64 \%$, for the Zavgren model having a level of accuracy is $83.64 \%$ and the error rate is $16.36 \%$.

\section{References}

[1] E. I. Altman, "Financial Ratios, Dsicriminant Analysis and the Prediction of Corporate Bankruptcy," J. Finance, vol. XXIII, 1968.

[2] A. BADAWI SALUY, B. PRAWIRA, and D. F. A. A. BUNTARAN, "The Influence of Leadership, Working Culture, and Working Environment for the Ministry of Administrative Reform and Bureaucracy,” Int. J. Bus. Econ. Aff., vol. 4, no. 5, pp. 224-234, 2019, doi: 10.24088/ijbea-2019-45003.

[3] M. Brealey, Myers, Fundamentals of Corporate Finance. 2016.

[4] A. D. and A. F. Edward I. Altman, "Z-SCORE MODELS' APPLICATION TO ITALIAN COMPANIES SUBJECT TO EXTRAORDINARY ADMINISTRATION,” EconPappers, vol. 04, no. 24-37, pp. 1-15, 2010. 
[5] Kothari C.R, Research Methodology Methods and Techniques, Second Rev. 2018.

[6] Priyono. (2016). Metode Penelitian Kuantitatif (Teddy Chandra (ed.); Edisi Revisi 2016). Zifatama Publishing.

[7] M. P. Radke, Explaining Financial Crises. 2018.

[8] H. D. Platt and M. B. Platt, "Predicting corporate financial distress: Reflections on choicebased sample bias," J. Econ. Financ., vol. 26, no. 2, pp. 184-199, 2002, doi: $10.1007 / \mathrm{bf02755985}$.

[9] Salim, M. N., \& Sudiono. (2017). an Analysis of Bankruptcy Likelihood on Coal Mining Listed Firms in the Indonesian Stock Exchange: an Altman, Springate, and Zmijewski Approaches. Eurasian Journal of Economics and Finance, 5(3), 99-108.

[10] Zavgren, C. V. (1985). Assessing the Vulnerability to Failure of American Industrial Firms: a Logistic Analysis. Journal of Business Finance \& Accounting, 12(1), 19-45.

[11] H. Shahdoust, M. R. Karimi, and B. Parvizi, "A Study of Bankruptcy prediction accuracy of Altman Adjusted and Zavgren models in firms accepted in Tehran stock exchange. (based on Altman adjusted model by Kordestani and colleagues)," World Essays J., vol. 3, no. 2, pp. 161-166, 2015.

[12] SafiyeMohammadi, "Studying the Efficiency and the Power of Predicting Bankruptcy of Firms Listed on the Stock Exchange using Springate, Fulmer, and Zavgren Models," Mediterr. J. Soc. Sci., vol. 7, no. 4, pp. 124-130, 2016.

[13] B. Pham Vo Ninh, T. Do Thanh, and D. Vo Hong, "Financial distress and bankruptcy prediction: An appropriate model for listed firms in Vietnam," Econ. Syst., vol. 42, no. 4, pp. 616-624, 2018, doi: 10.1016/j.ecosys.2018.05.002.

[14] N. Puro et al., "Financial Distress and Bankruptcy Prediction: A Comparison of Three Financial Distress Prediction Models in Acute Care Hospitals," J. Health Care Finance, pp. 1$15,2019$. 